\title{
Transformations in the labor market in the Americas - or is it crisis?
}

¿Crisis o transformación del mundo laboral en las Américas?

Crise ou transformations du monde du travail dans les Amériques?

\section{Donna Kesselman}

Translator. Michael Hinchliffe

\section{OpenEdition}

\section{Journals}

Electronic version

URL: https://journals.openedition.org/ideas/3073

DOI: 10.4000/ideas.3073

ISSN: 1950-5701

This article is a translation of:

Crise ou transformations du monde du travail dans les Amériques ? - URL : https://

journals.openedition.org/ideas/1022 [fr]

Other translation(s):

¿Crisis o transformación del mundo laboral en las Américas? - URL : https://journals.openedition.org/ ideas/3079 [es]

Crise ou transformação do mundo dos negócios nas Américas? - URL : https://

journals.openedition.org/ideas/4722 [pt]

Publisher

Institut des Amériques

Electronic reference

Donna Kesselman, "Transformations in the labor market in the Americas - or is it crisis?", IdeAs

[Online], 5 | 2015, Online since 26 July 2018, connection on 20 October 2022. URL: http:// journals.openedition.org/ideas/3073 ; DOI: https://doi.org/10.4000/ideas.3073

This text was automatically generated on 20 October 2022

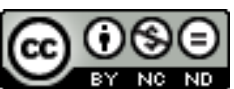

Creative Commons - Attribution-NonCommercial-NoDerivatives 4.0 International - CC BY-NC-ND 4.0 https://creativecommons.org/licenses/by-nc-nd/4.0/ 


\title{
Transformations in the labor market in the Americas - or is it crisis?
}

\author{
¿Crisis o transformación del mundo laboral en las Américas? \\ Crise ou transformations du monde du travail dans les Amériques?
}

Donna Kesselman

Translation : Michael Hinchliffe

1 Is labor in the Americas in a state of crisis? If so, how is the crisis particular to this hemisphere? How is it inflected from North to South America, and in all the separate countries? Or is the problem rather that of discerning configurations that are emerging as a result of the globalization of the labor market in the $21^{\text {st }}$ century?

2 These are the questions raised in this issue of IdeAs, which concentrates on laborrelated phenomena, where the previous issue was centered more generally on "Crises and crisis-induced effects in the Americas".

3 It has become customary to refer to the generation-long labor crisis that has been affecting industrialized countries. Financial globalization, coupled with technical and technological innovation, has brought down the frontiers that contained both commerce and information, and has given rise to neoliberal public policies which eat away at time-honored institutions originally set up for the purpose of regulation and social redistribution. As far as the labor and employment market is concerned, the socalled "Great Recession" of 2008 did no more than accelerate a process that was already under way, a general observation that calls for more specific qualification.

4 Far from being a homogenous process, globalization is an affair of standardization and more particularly, of differentiation (Azaïs C., 2010). The "globalizing world labor market" is in fact a disparate process involving both national specificities and institutional specificities at other levels, as well as interactions between multiple social players, aspects which must all be taken into account (Kesselman D., 2010a; Giraud O., 2012). With regard to labor, differentiation arises on the one hand from collective and 
individual resistance to the pressure from transnational firms for ever greater flexibility and lower costs. Resistance may take the form, say of social action for the defense of public transport or of public health and education in a dynamic country like Brazil; or it may equally occur as a demand for social rights in such an unexpected country as the United States, where, for the first time, as imposed by a public authority, certain federal States are now making paid vacations for wage-earners mandatory (Thévenard E., 2015). On the other hand, by virtue of its susceptibility to the pressure of local interests, flexibility also favors differentiation.

of course, comparable, if not overlapping, situations are to be found throughout the Americas, from South to North. In the previous issue of IdeAs, Laurence Whitehead advances a series of contextual factors that argue in favor of a specificity of experience in what might be called the "New World" (Whitehead L., 2013). Latin American countries have in common the fact that they belong to the so-called "Global South", a notion that is part of the development of capitalism. This term, more recent than the erstwhile "under developed" or "third world" countries, refers to national economies that do not have direct access to the world market. Formerly colonized or otherwise dominated by developed countries, theirs is a passive experience of commercial, and later capitalist, prosperity as a result of the physical displacement of their wealth to feed that of the North. Some of these countries are today considered, in politically correct language, as developing countries, others as emerging countries. Despite the fact that the meaning of this latter category is shifting rapidly (Salama P., 2014), its implicit connotations encourage confusion.

6 As was the case with the 1960s expression "developing countries", the term "emerging countries" suggests a linear historical trajectory, calqued on that followed by the wealthy North, undergoing its own industrial and post-industrial revolutions. But this vision of a smooth progression of capitalist growth in traditional western democracies does not tally with how the international division of labor has evolved. Furthermore, the political and social conditions particular to each country in the South, together with the tensions constitutive of the world market, preclude any simplified -or glorified-conception of economic history reproducing itself.

7 It would appear that the heterogeneous nature of Latin American economies was confirmed by the crisis of 2008. As Carlos Quenan shows, the "reality of economically divergent trajectories" applies even to countries in many ways comparable, such as Mexico and Brazil. In Brazil, several factors combined to attenuate the impact of the financial crisis, whereas in Mexico, its consequences were particularly "virulent both for the economy and the population". Countries principally dependent on revenue from exported oil each reacted differently to the crisis (Quenan C., 2013).

8 These differences could be explained as a result of different national models. It can even be argued that there are distinct "varieties of capitalism", specific to Latin America and articulated between the two poles constituted by the two countries possessing the largest economies (Bizberg I., 2012; Théret B., 2002; Marques-Pereira J. et Théret B., 2004) and especially differentiated on matters to do with labor. For Bizberg, Brazil can be described as "State-led/inward oriented", with the State playing a key role in the orientation of economic activity towards the home market, thereby reinforcing the basis for its active integration in the world market. In the article presented here, Marcia Leite and Carlos Salas corroborate this conception. Their study of how labor conditions have evolved points to a reduction of social inequality owing to 
the fact that a greater number of under-privileged people are gaining access to higher skilled jobs, a tendency which the crisis has not inflected and which is a feature of the Brazilian development model. At the directly opposite pole, evidenced by Mexico, the State has a subsidiary capacity, articulating a productive apparatus that faces primarily outwards. State action is limited to regulation and the promotion of national capital by means of counter-cyclical intervention in what might be called "State-regulated/ externally oriented capitalism". Elodie Segal, for whom Mexican society is "disfigured by inequality", develops this idea in her contribution. Her study portrays a production model which, in the name of modernization, is driven by the requirements of finance and broker clients. The internal pressures this generates lead to deregulation, individualization, and, in the case of the most vulnerable segments of the population, reductions in worker rights. This is indeed what has happened in Mexico, where the minimum wage is one of the lowest in Latin America.

Other countries combine characteristics of both the above models (Bizberg I., 2012), one such being Chile, as Guillermo Wormald and Maria Paz Trebilock argue in their study. They analyze the relationship between labor and social cohesion in urban environments in Chile, showing how a "new merchant society" is emerging, displacing former networks and appearing more and more as a mechanism for coordinating access to job opportunities. To what extent does labor still function as a vector for the promotion of social congress, social valorization and citizenship? Towards the end of the last century Latin America was presented as a potential "social laboratory" for the future of labor in the wealthy North, a position later reiterated by Beck via his conception of the "Brazilianization of the West" (Beck Ü., 2002), but it would rather seem that the development in Chile serves to bear out the hypothesis developed in this issue of IdeAs, and elsewhere, according to which ongoing practices in the United States concerning the market-based articulation of labor and social benefits could reverse the direction of the experiment.

Thus the positing of a globalization revolving around differentiation, both between and within economies and societies, seems particularly relevant with regard to the labor and employment markets. National situations are not easily comparable because of specific historical conditions at work in the construction of each social State and each system of professional relationships. One instance of this is how the minimal and fragmented nature of institutions governing social regulation in the United States has produced large discrepancies in employment relationship from region to region and from company to company. And the US situation as a whole is very different from that of neighboring Canada which is far more protective (Lapointe P.-A., 2013; Kesselman D., 2007). With South American countries, both socio-political history and differences in degree or strategy with regard to development must be taken into account.

11 Certain studies in this issue deal with the subject of professional relationships and the collective struggles that have, within their national contexts, aimed at obviating the consequences of neoliberal globalization. Though weakened, trade union power, with its counter-balancing effects, is still a player in the game.

In Guatemala clothing factories constitute one of the main sectors registering an increase in formally declared jobs, particularly for women, in a country where the vast majority of the active population have informal jobs. Nevertheless, precariousness and dismal working conditions prevail in these maquilas, which also practice ferocious antiunionism. Yet, as Quentin Delpech shows from investigations in situ, despite all the 
obstacles and hindrances placed in the way of the proper exercise of union rights, these workers are not capitulating.

Venezuela is an exceptional case. Thomas Posado provides a perspective from inside the union movement on the drastic changes that have occurred since Hugo Chavez came to power. The Chavist regime, with its bias in favor of popular interest and its policy of resistance against the dictates of world economic and financial entities, has had much influence both on the positions taken up by worker organizations founded in a by-gone age and on the renewal of labor unions in the country.

Also to be found in this issue of IdeAs is a comparative analysis of labor unions in North America. How is it that the rate of union membership in the United States is one of the lowest in the western world, whereas in Canada, it is one of the highest? An interview with Paul-André Lapointe, a specialist in professional relationships at Laval University (Quebec), suggests an explanation for this apparently paradoxical situation given not only the social and economic similarities between the two countries but also their common labor history, comprising the adoption of the same legislative apparatus for professional relationships in industry and the establishment of the so called International Unions, covering both the US and Canada. Lapointe's account retraces this evolution, intertwined at first then, from the 1960s, increasingly divergent, while at the same time examining the challenges confronting workers and their organizations today. Seen through the prism of union rights, the political and social culture of the different Canadian provinces is also apparent in its wide diversity.

These national experiences of economic growth and the defense of collective social interests engender differentiations in terms of social equality. Any judgment of the subjective or objective situations of labor from North to South America and within each separate society must go beyond macroeconomic statistics. High growth rates and the extension of wage-earning throughout Latin American countries, despite the financial crisis, fascinate their neighbors in the North. Yet these conditions have by no means resulted in the establishment of employment relationships linked to social benefits on the level reached historically by the North. Indeed, the South is also experiencing a multiplication of the number of precarious jobs (Gigilia A., 2014; Rosenfield C., 2014).

Similarly, there has been no drop in informal employment in Latin America, merely a shift in its appearance and nature (Azaïs C. and Lehalleur M., 2014). Guillermo Wormald and Maria Paz Trebilcock demonstrate the complexity of this phenomenon in Chile. Formal, salaried employment is on the rise for both sexes of all ages through all the deciles on the salary scale and, what is more, under the form of open-ended contracts. However, placing aside the case of the uppermost decile (the $10 \%$ of employees with the highest salaries), these contracts are a long way from providing the level of protection enjoyed by European wage earners in particular.

Thus, in the context of neoliberal globalization, the question remains as to what social perspectives actually exist even in economies on the verge of unprecedented development if the most extensive framework of redistribution in Northern countries is condemned to relentless shrinkage.

Outcomes are of course not written in advance. The contributions to this issue of IdeAs help to pose the initial question in the most currently relevant terms: is there a labor crisis, or are we rather witnessing new configurations of labor, configurations characteristic of globalization and harbingers of a new century (D'Amours M. et al., 
2015)? The answer will depend not only on the play of the agencies involved, but also on the health of the system itself.

After the planet-wide crisis sparked by the collapse of the US financial markets in 2008, there were announcements that recovery was on the way. Early in 2014, the French daily Le Monde was boasting that "the IMF sees the premises of a 'stronger, more widereaching recovery"' (Guélaud C., 2014). But then the IMF back-pedaled: on the eve of the Davos world economic forum of January 2015, it scaled down its estimations. The slackening in investment and in potential growth in most of the "big countries" was continuing and recovery both in the euro zone and Japan was slower than predicted. Emerging and developing countries, BRICS included, despite their much-vaunted dynamism in the early 2000s, were going through a bad patch, particularly in SubSaharan Africa and Latin America, thanks, amongst other factors, to the plunge in the price of staple products. The only IMF predictions revised upwards were those relative to the US economy (IMF, 2015).

As a kind of inertia wheel for the entire world economy, a more dynamic US economy should be carrying the labor market forward, its own to start with. Yet this is not what Donna Kesselman finds: in her article she argues that the model of the "American Job Machine" is floundering in structural crisis. Olivier Fraysse looks at more long-term issues, suggesting that the almost complete disappearance of the paygo system for pensions has implications that go way beyond the fate of a particular social benefit because what it in fact reveals is the elision of the very foundations of the American dream. Christian Azaiis, in his contribution, provides a theoretical study of the transformations affecting labor in a "globalizing world", asking whether these are an amplification of an already ongoing process or, rather, a crisis bringing an outright change in nature.

Whitehead, Laurence, «'Crisis' in the Americas: Is there a Regionally Distinctive Kind?», IdeAs, $\mathrm{n}^{\circ}$ 4, otoño de 2013, http://ideas.revues.org/611

\section{BIBLIOGRAPHY}

Our readers will of course judge for themselves. With their work on seven different American countries, the sixteen contributors to this issue of IdeAs together open up a rich panorama and a wealth of perspectives on the evolution and emergence of labor and employment markets, on the shifting nature of the various phenomena, on the role of old and new players, all so many pointers to the shape of societies to come. We hope our readers will find this panorama a stimulating one.

Azaïs, Christian, « Amérique du Sud : Travail ; Syndicalisme », in Michel Bertrand, Antoine Coppolani, Isabelle Vagnoux, Jean-Michel Blanquer (dir.), Dictionnaire des Amériques, Paris, Laffont Collection Bouquins, publicación prevista en 2016.

Azaïs, Christian (dir), «Introduction», Labour and Employment in a Globalizing World: Autonomy, collectives and political dilemmas, Brussels, Peter Lang. 2010. 
Azaïs, Christian et Pepin-Lehalleur Marielle (dir.), Modes de gouvernance dans quatre métropoles latino-américaines (Buenos Aires, Caracas, Mexico et São Paulo) : entre logiques institutionnelles et acteurs, Bruxelles, P.I.E. Peter Lang Ed., 2013.

Beck, Ülrich, The Brave New World of Work, Oxford, Polity Press, 2000.

Bizberg, Ilan, «Types of capitalism in Latin America», Revue Interventions économiques, $\mathrm{n}^{\circ}$ 47, 2012, p. 1-26, http://interventionseconomiques.revues.org/1772.

D’Amours, Martine, Soussi, Sid Ahmed, Tremblay, Diane-Gabrielle (dir.), Repenser le travail : Des concepts nouveaux pour des réalités transformées, Québec, Presses de l'Université de Québec, 2015.

Fondo Monetario Internacional (FMI), «Crecimiento mundial revisado a la baja, pese al abaratamiento del petróleo y la aceleración del crecimiento estadounidense», Boletín del FMI, 20 de enero de 2015, http://www.imf.org/external/Spanish/pubs/ft/survey/so/2015/NEW 012015AS.htm, consultado el 2 de abril de 2015.

Giglia, Angela, «Trabajo precario y redes de solidaridad. El caso de los gasolineros en la ciudad de México», in Angela Giglia y Adelina Miranda (coords), Precariedad urbana y lazos sociales. Una perspectiva comparativa entre México e Italia, México, UAM-Juan Pablos editores, 2014, p. 109-137.

Giraud, Olivier, « L'analyse scalaire des régimes d'action publique en Europe : l'apport méthodologique des comparaisons internationales ", Revue internationale de politique comparée, vol. $19, n^{\circ} 2,2012$, p. $15-36$.

Guélaud, Claire, «Le FMI entrevoit une reprise 'plus forte et plus large' », Le Monde, 8 avril 2014, http://www.lemonde.fr/economie/article/2014/04/08/le-fmi-entrevoit-une-reprise-plus-forteet-plus-large_4397717_3234.html\#ZAXV65cyXjha3dYj.99, consultado el 5 de marzo de 2015.

Hall, Per A., Soskice, David, Varieties of Capitalism, Oxford University Press, 2001.

Kesselman, Donna, « Travail et salariat aux États-Unis : Quels droits, quelles perspectives?», Revue Française d'Etudes Américaines, nº 111, 2007, p. 6-26.

Kesselman, Donna, «A Globalizing labour and employment market» (Postface), in Christian Azaïs (Dir.), Labour and Employment in a Globalizing World: Autonomy, collectives and political dilemmas, Brussels, Peter Lang, 2010a, p. 267-273.

Kesselman, Donna, «Trabalho precário e precarização institucional nos Estados-Unidos», Sociologias, vol. 12, $\mathrm{n}^{\circ} 25$, noviembre/diciembre, 2010b, p. 66-100.

Lapointe, Paul-André (Dir.), La qualité du travail et de l'emploi au Québec. Données empiriques et cadres conceptuels, Québec, Presses de l'Université Laval, 2013.

Marques-Pereira, Jaime et Théret, Bruno, «Mediaciones institucionales de regulación social y dinámicas macroeconómicas: los casos de Brasil y México» in Carlos Alba e Ilán Bizberg (Dir.), Democracia y Globalización en México y Brasil, México, El Colegio de México, 2004.

Quenan, Carlos, «América latina frente a la crisis económica internacional: buena resistencia global y diversidad de situaciones nacionales», IdeAs, nº 4, otoño de 2013, http:// ideas.revues.org/780.

Rosenfield, Cinara (dir), «Trabalho, emprego e precarização social», Sociologias, vol n $12, n^{\circ} 25$, noviembre/diciembre de 2010.

Salama, Pierre, Des pays toujours émergents ?, Paris, La Documentation Française, 2014.

Théret, Bruno, Protection sociale et fédéralisme. L'Europe dans le miroir de l'Amérique du Nord, Montréal, Presse de l'Université de Montréal - Peter Lang, 2002. 
Thevenard, Evelyn, «Paid Family Leave as Public Policy: A View from the States», in Gérard Gomez y Donna Kesselman (Dir.), Les femmes au travail dans les Amériques, Aix-en-Provence, Presses Universitaires de Provence (PUP), publicación prevista en 2015.

\section{AUTHORS}

\section{DONNA KESSELMAN}

Donna Kesselman est Professeure des Universités à l'Université Paris-Est Créteil. Elle publie largement sur les questions du travail, de l'emploi et des relations professionnelles, en proposant une perspective comparative, (France, États-Unis, Brésil, Canada). Elle est co-rédactrice d'un recueil d'articles publié aux Presses Universitaires de Provence, articles issus des communications qui ont été faites lors du Congrès de l'IDA de 2013 "Les Femmes dans les Amériques", et plus particulièrement de l'axe thématique "Les femmes et le travail dans les Amériques". Elle a co-rédigé des études de la DARES sur les relations professionnelles. Elle est au bureau du RT 18 de l'Association Française de Sociologie traitant des relations professionnelles. 